\title{
ITO-Free Semitransparent Organic Solar Cells Based on Silver Thin Film Electrodes
}

\author{
Zhizhe Wang, Chunfu Zhang, Dazheng Chen, Shi Tang, Jincheng Zhang, Li Sun, \\ Ting Heng, and Yue Hao
}

State Key Discipline Laboratory of Wide Band Gap Semiconductor Technology, School Of Microelectronics, Xidian University, 2 South Taibai Road, Xian 710071, China

Correspondence should be addressed to Chunfu Zhang; cfzhang@xidian.edu.cn and Yue Hao; yhao@xidian.edu.cn

Received 11 April 2014; Revised 9 June 2014; Accepted 11 June 2014; Published 30 June 2014

Academic Editor: Chao-Rong Chen

Copyright (C) 2014 Zhizhe Wang et al. This is an open access article distributed under the Creative Commons Attribution License, which permits unrestricted use, distribution, and reproduction in any medium, provided the original work is properly cited.

ITO-free semitransparent organic solar cells (OSCs) based on $\mathrm{MoO}_{3} / \mathrm{Ag}$ anodes with poly(3-hexylthiophene) and [6,6]-phenylC61-butyric acid methyl ester films as the active layer are investigated in this work. To obtain the optimal transparent $\left(\mathrm{MoO}_{3}\right) / \mathrm{Ag}$ anode, ITO-free reference OSCs are firstly fabricated. The power conversion efficiency (PCE) of 2.71\% is obtained for OSCs based on the optimal $\mathrm{MoO}_{3}(2 \mathrm{~nm}) / \mathrm{Ag}(9 \mathrm{~nm})$ anode, comparable to that of ITO-based reference OSCs (PCE of 2.85\%). Then based on $\mathrm{MoO}_{3}(2 \mathrm{~nm}) / \mathrm{Ag}(9 \mathrm{~nm})$ anode, ITO-free semitransparent OSCs with different thickness combination of Ca and Ag as the cathodes are investigated. It is observed from our results that OSCs with $\mathrm{Ca}(15 \mathrm{~nm}) / \mathrm{Ag}(15 \mathrm{~nm})$ cathode have the optimal transparency. Meanwhile, the PCE of $1.79 \%$ and $0.67 \%$ is obtained for illumination from the anode and cathode side, respectively, comparable to that of similar ITO-based semitransparent OSCs (PCE of $1.59 \%$ and $0.75 \%$ for illumination from the anode and cathode side, resp.) (Sol. Energy Mater. Sol. Cells, 95, pp. 877-880, 2011). The transparency and PCE of ITO-free semitransparent OSCs can be further improved by introducing a light couple layer. The developed method is compatible with various substrates, which is instructive for further research of ITO-free semitransparent OSCs.

\section{Introduction}

Due to the advantage of low cost, light weight, simple process, flexibility, and possibility of roll-to-roll mass production [15], organic solar cells (OSCs) have become a highly attractive research topic over the past decade. With the development of the research, obvious progress has been made. Recently, even OSCs with certified power conversion efficiency (PCE) above $10 \%$ have been reported [6], which has approached the requirement of commercialization.

However, there are still some bottlenecks for commercialization of OSCs. One awkward drawback is that most organic materials can cover only a fraction of the solar spectrum, and inefficient light harvest results in the low photocurrent [7]. One efficient way to enhance broad spectral absorption of OSCs is the realization of organic tandem solar cells based on complementary thin absorber materials. As we all know, the semitransparent electrode $[8,9]$ or recombination contact used to connect two subcells is of vital importance in the fabrication of tandem solar cells.
Meanwhile, semitransparent OSCs make sense from the aspect of application. For example, these semitransparent OSCs can be employed as the windows of our houses and cars, providing electric power without occupying living space. Thus, various semitransparent electrodes for OSCs have been developed in recent years [10-12]. It should be noted that good transparency and high PCE are required simultaneously for the application of semitransparent OSCs.

Another bottleneck for commercialization of OSCs stems from the commonly used transparent anode in the fabrication of OSCs-indium tin oxide (ITO) sputtered on glass. Although ITO has excellent properties in optical transparency and electrical conductivity, it is unsuitable for cheap roll-to-roll fabrication of OSCs, which relies on the flexible electrodes with low cost. For example, the scarce indium source and stringent process conditions (usually sputter) result in high cost for ITO electrode [13]. Meanwhile, both the brittleness of ITO electrode and high temperature condition in the fabrication of ITO make it unsuitable for the roll-to-roll mass production of OSCs [14]. Thus, more and 
more attention has been focused on alternative transparent conductive electrodes. Indium-free transparent conducting oxides (such as Ga-doped $\mathrm{ZnO}$ (GZO) and Al-doped $\mathrm{ZnO}$ (AZO)) [15-17], poly(3,4-ethylenedioxythiophene):poly(styrenesulfonate) (PEDOT:PSS) [18, 19], Ag nanowires [14, 20], graphene [13], and carbon nanotubes [21] are used as the alternative of ITO electrode. However, although GZO or AZO has a lower cost than ITO, the fabrication of these electrodes still needs sputter. Although the PEDOT:PSS electrode can be easily fabricated by solution method, the resistivity of this electrode is still a little too high $[22,23]$. Since the surfaces of Ag nanowire, graphene, and carbon nanotube electrodes are usually rough, charge injection into or extraction from active layer has been restricted $[13,14,24]$. In addition, complex film processing of these electrodes also makes them inappropriate for application in large-scale OSCs $[13,14,24]$.

On the contrary, a smooth metal thin film (e.g., Ag) can be easily fabricated by thermal evaporation, compatible with the mass production process. Moreover, due to their intrinsic flexibility and high conductivity [24], metal thin film electrodes are suitable for the flexible substrates in roll-to-roll mass production of OSCs. Thus, more and more attention is attracted to this topic. Various transparent metal thin film electrodes (such as $\mathrm{Au}$ [25], $\mathrm{Ag}$ [26], $\mathrm{Cu}$ [27], $\mathrm{Cu} / \mathrm{Ni}$ [28], and $\left.\mathrm{MoO}_{3} / \mathrm{Au} / \mathrm{MoO}_{3}[24]\right)$ are reported and employed in the fabrication of OSCs.

However, in the previous work, semitransparent OSCs are usually fabricated on ITO electrodes. Here, we have reported ITO-free semitransparent OSCs based on Ag thin film anodes. The ITO-free semitransparent OSC has combined the advantages of ITO-free OSCs and semitransparent OSCs, solving two bottlenecks discussed above for commercialization of OSCs simultaneously. At first, ITO-free reference OSCs based on $\left(\mathrm{MoO}_{3}\right) / \mathrm{Ag}$ anodes are fabricated, with poly(3-hexylthiophene) (P3HT) and [6,6]-phenyl-C61butyric acid methyl ester (PCBM) films as the active layer. The optimal anode, $\mathrm{MoO}_{3}(2 \mathrm{~nm}) / \mathrm{Ag}(9 \mathrm{~nm})$ anode, is obtained. The PCE of $2.71 \%$ is achieved for corresponding OSCs (also the highest PCE among all the ITO-free reference OSCs), comparable to that of ITO-based reference OSCs (PCE of $2.85 \%)$. Then based on this $\mathrm{MoO}_{3}(2 \mathrm{~nm}) / \mathrm{Ag}(9 \mathrm{~nm})$ anode, ITO-free semitransparent OSCs with different thickness combination of $\mathrm{Ca}$ and $\mathrm{Ag}$ as the cathodes are fabricated. It is observed from our results that OSCs with $\mathrm{Ca}(15 \mathrm{~nm}) / \mathrm{Ag}$ $(15 \mathrm{~nm})$ cathode have the optimal transparency. Meanwhile, the PCE of $1.79 \%$ (illuminated from the anode side) and $0.67 \%$ (illuminated from the cathode side) is obtained for the corresponding device, comparable to that of similar ITObased semitransparent OSCs (PCE of $1.59 \%$ and $0.75 \%$ for illumination from the anode and cathode side, resp.) $[10,11]$. The result is instructive for further research of ITO-free semitransparent OSCs.

\section{Experimental Details}

2.1. Material and Substrate Preparation. P3HT was purchased from Rieke Metals Inc., PCBM was purchased from Nano$\mathrm{C}$ Inc., and 1,2-dichlorobenzene and $\mathrm{MoO}_{3}$ were provided from Aldrich Inc. All the materials were used without any further purification. P3HT and PCBM were dissolved in 1,2dichlorobenzene with a concentration of $20 \mathrm{mg} / \mathrm{mL}$, respectively. They were mixed in a weight ratio of $1: 0.8$ and stirred at room temperature for $2 \mathrm{~h}$ before use. Glass substrates were cleaned sequentially with detergent (Decon 90, UK), deionized water, acetone, and ethanol in an ultrasonic bath for about $15 \mathrm{~min}$.

2.2. Electrode Deposition and Characterization. Cleaned glass substrates were dried with a nitrogen $\left(\mathrm{N}_{2}\right)$ flow and then transferred into a custom-made multichamber ultrahigh vacuum evaporation system. The $\left(\mathrm{MoO}_{3}\right) / \mathrm{Ag}$ electrodes were deposited on glass by thermal evaporation at a vacuum pressure $<5 \times 10^{-4} \mathrm{~Pa}$, with a evaporation rate of 0.02 and $0.1 \mathrm{~nm} / \mathrm{s}$ for $\mathrm{MoO}_{3}$ and $\mathrm{Ag}$, respectively. The substrates during deposition were at room temperature. The thicknesses and evaporation rates of $\mathrm{MoO}_{3}, \mathrm{Ag}, \mathrm{Al}$, and $\mathrm{Ca}$ were estimated in situ with a calibrated quartz crystal monitor.

The spectral transmission and reflectance were recorded by using an UV-VIS-NIR spectrophotometer (Lambda 950, Perkin Elmer). Since transmission was measured relative to air, the reflection of the glass substrate was included. The sheet resistances of the samples were measured by using a fourpoint probe setup. The transmission electron microscope (TEM) cross-sectional image was taken by a FEI Tecnai G2 F20 S-Twin transmission electron microscope.

2.3. Device Fabrication and Measurement. After the electrode deposition, a $10 \mathrm{~nm}$ thick $\mathrm{MoO}_{3}$ layer was first thermally evaporated onto the substrates as the hole transport layer with high work function. Then P3HT:PCBM solution was spin-coated onto the samples at $1000 \mathrm{rpm}$ for $60 \mathrm{~s}$ in a $\mathrm{N}_{2}$ glove box attached to the vacuum system, followed by annealing at $150^{\circ} \mathrm{C}$ for $10 \mathrm{~min}$. Finally, $\mathrm{Ca}$ and $\mathrm{Ag}$ with different thicknesses were further deposited on top of the active layer as the cathode through a metal shadow mask to finish the ITO-free semitransparent OSCs, resulting in an active solar cell area of $6 \mathrm{~mm}^{2}$. ITO-free and ITO-based reference OSCs were fabricated in nearly the same procedure except that they were postannealed after the deposition of the $70 \mathrm{~nm}$ thick Al cathode. Device geometry of ITO-free reference or ITO-free semitransparent OSCs is illustrated in Figure 1(a). TEM cross-sectional image of corresponding ITO-free semitransparent OSCs is shown in Figure 1(b). The current density-voltage $(J-V)$ characteristics were measured with a source measurement unit 2400 SMU (Keithley, USA) and simulated AM 1.5 G sun light (San-Ei Electric) in air without any device encapsulation. The illumination intensity was kept at $100 \mathrm{~mW} / \mathrm{cm}^{2}$ through using a Si standard solar cell calibrated by the National Renewable Energy Laboratory (NREL).

\section{Results and Discussion}

To fabricate ITO-free semitransparent OSCs, ITO-free reference OSCs with $\mathrm{Al}$ cathode were firstly investigated so that we can obtain the optimal transparent Ag thin film anode. 


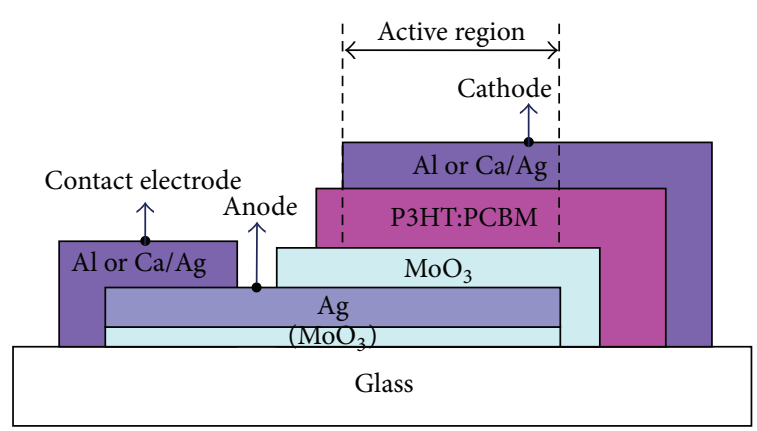

(a)

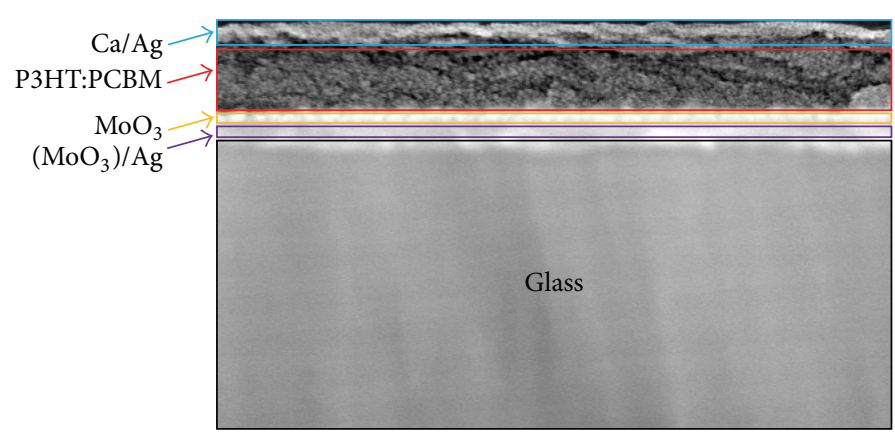

(b)

Figure 1: (a) Device geometry of ITO-free reference or ITO-free semitransparent OSCs based on $\left(\mathrm{MoO}_{3}\right) / \mathrm{Ag}$ anodes and (b) TEM crosssectional image of ITO-free semitransparent OSCs.

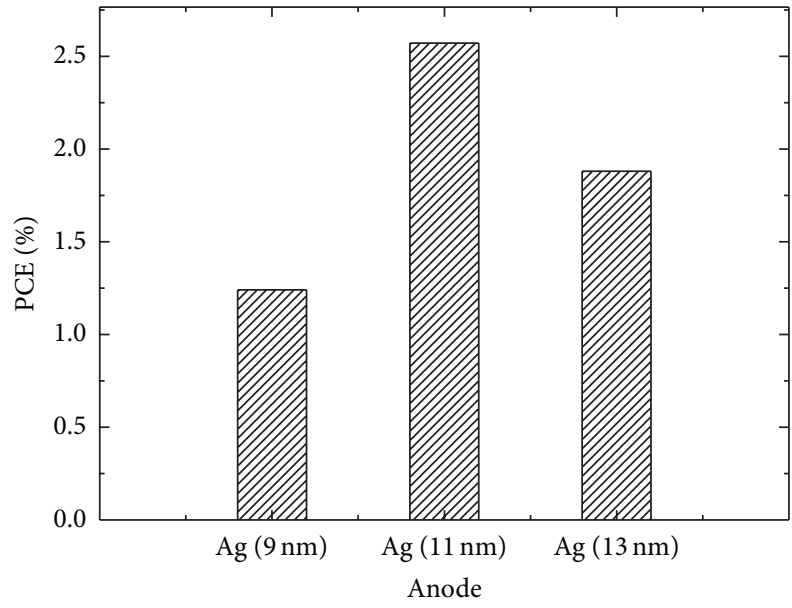

VIIS PCE

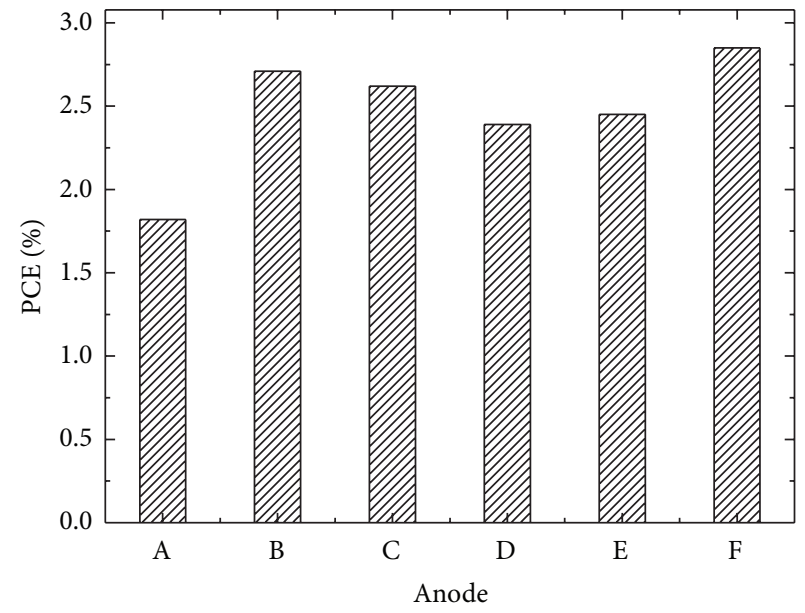

VIII PCE

(a)

(b)

FIgure 2: The PCE of ITO-free reference OSCs fabricated on the (a) Ag or (b) $\mathrm{MoO}_{3} / \mathrm{Ag}$ anodes. For comparison, the PCE of the ITO-based reference OSC is also shown in (b). The characters A, B, C, D, E, and F on the $X$ axis of (b) indicate $\left.\mathrm{MoO}_{3}(2 \mathrm{~nm}) / \mathrm{Ag}(7 \mathrm{~nm}), \mathrm{MoO} 3 \mathrm{~nm}\right) / \mathrm{Ag}$ $(9 \mathrm{~nm}), \mathrm{MoO}_{3}(2 \mathrm{~nm}) / \mathrm{Ag}(11 \mathrm{~nm}), \mathrm{MoO}_{3}(10 \mathrm{~nm}) / \mathrm{Ag}(9 \mathrm{~nm}), \mathrm{MoO}_{3}(10 \mathrm{~nm}) / \mathrm{Ag}(11 \mathrm{~nm})$, and ITO anode, respectively.

As we all know, the thermally evaporated Ag layer prefers Volmer-Weber growth, which starts from isolated island [29]. Thus, Ag atoms agglomerate to form isolated clusters at first when Ag is thermally evaporated on glass substrates. It can cause surface plasmon resonances with light in the visible range which significantly reduces the film transparency [30]. With the increase of the Ag film thickness, the percolation threshold of Ag is reached, which is defined as equivalent thickness where isolated metal islands start to connect and form a continuous layer [31]. If the thickness of $\mathrm{Ag}$ layer is over this transition point, the transparency is decreased with an increased conductivity. Thus the best performance of OSCs based on Ag thin film anode is generally achieved close to the percolation threshold, indicating the best tradeoff between increasing conductivity and decreasing transparency.

The PCE of ITO-free reference OSCs fabricated on the Ag or $\mathrm{MoO}_{3} / \mathrm{Ag}$ anodes is illustrated in Figures 2(a) and 2(b), respectively. For comparison, the PCE of the ITO-based reference OSC is also shown in Figure 2(b). As shown in Figure 2(a), the PCE of $2.57 \%$ is obtained for OSCs based on $\mathrm{Ag}(11 \mathrm{~nm})$ anode, the best performance among the devices fabricated on pure $\mathrm{Ag}$ anodes. It may suggest that the percolation threshold of $\mathrm{Ag}$ in our case is approximately $11 \mathrm{~nm}$. Then a $\mathrm{MoO}_{3}$ interlayer between the Ag layer and glass substrate is introduced. Since a closed $\mathrm{MoO}_{3}$ layer is formed with the approximate thickness of $4 \mathrm{~nm}$ [32], two different thicknesses of $\mathrm{MoO}_{3}(2 \mathrm{~nm}$ or $10 \mathrm{~nm})$ are chosen here. It can be observed from Figure 2 that the introduction of the $\mathrm{MoO}_{3}$ interlayer can improve the performance of OSCs effectively, particularly when the thickness of $\mathrm{MoO}_{3}$ is $2 \mathrm{~nm}$. The PCE of OSCs based on $\mathrm{MoO}_{3}(2 \mathrm{~nm}) / \mathrm{Ag}(9 \mathrm{~nm})$ anode is even enhanced to $2.71 \%$ (also the highest PCE among all the ITO-free reference OSCs), comparable to that of ITObased reference OSCs (PCE of 2.85\%). Improvement in the performance of the Ag thin film electrode can be attributed 


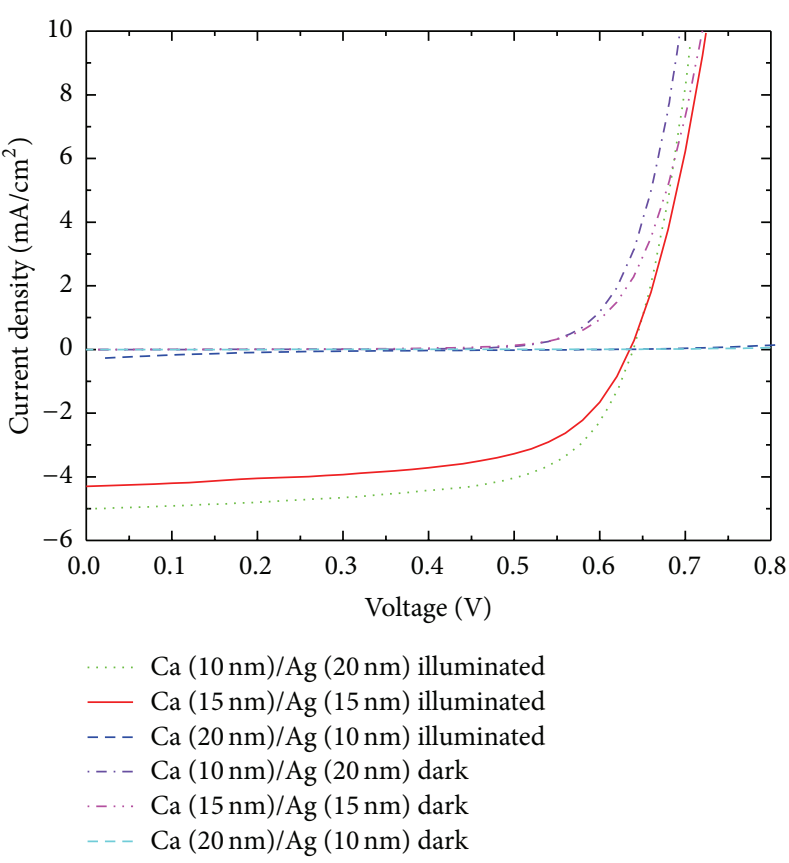

(a)

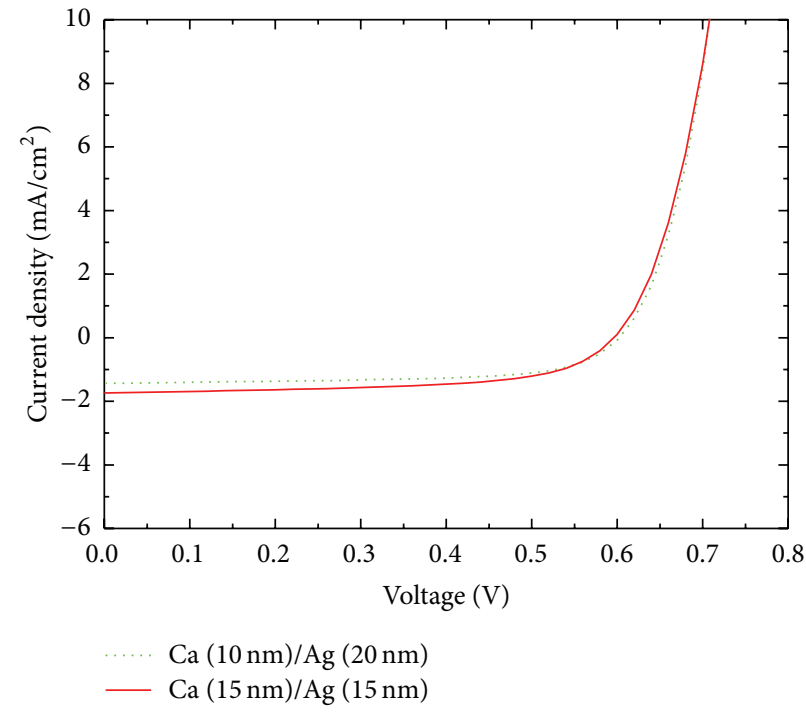

(b)

FIgURE 3: $J-V$ characteristics of devices $\mathrm{MoO}_{3}(2 \mathrm{~nm}) / \mathrm{Ag}(9 \mathrm{~nm}) / \mathrm{MoO}_{3}(10 \mathrm{~nm}) / \mathrm{P} 3 \mathrm{HT}: \mathrm{PCBM} / \mathrm{Ca} / \mathrm{Ag}$ with different thickness combination of $\mathrm{Ca}$ and $\mathrm{Ag}$ as the cathodes when illuminated from the (a) anode side and (b) cathode side. Corresponding dark $J-V$ curves are also shown in (a) for comparison.

TABLE 1: Photovoltaic performance parameters of ITO-free semitransparent OSCs with different thickness combination of Ca and Ag as the cathodes illuminated from the anode (bottom) and cathode (top) side.

\begin{tabular}{lcccccccc}
\hline $\mathrm{Ca}(\mathrm{nm})$ & $\mathrm{Ag}(\mathrm{nm})$ & Illumination & $V_{\mathrm{OC}}(\mathrm{V})$ & $J_{\mathrm{SC}}\left(\mathrm{mA} / \mathrm{cm}^{2}\right)$ & $\mathrm{FF}(\%)$ & $\mathrm{PCE}(\%)$ & $R_{\mathrm{S}}\left(\Omega / \mathrm{cm}^{2}\right)$ & $R_{\mathrm{Sh}}\left(\mathrm{k} \Omega / \mathrm{cm}^{2}\right)$ \\
\hline 10 & 20 & Bottom & 0.64 & 5.03 & 62.4 & 2.01 & 1.2 & 1.08 \\
10 & 20 & Top & 0.60 & 1.44 & 64.6 & 0.56 & 1.3 & 5.07 \\
15 & 15 & Bottom & 0.64 & 4.70 & 59.5 & 1.79 & 2.1 & 1.12 \\
15 & 15 & Top & 0.60 & 1.90 & 59.3 & 0.67 & 1.7 & $/$ \\
20 & 10 & Bottom & 0.62 & 0.31 & 10.1 & 0.02 & $/$ \\
20 & 10 & Top & $/$ & $/$ & $/$ & $/$ & $/$ \\
\hline
\end{tabular}

to decreased percolation threshold of $\mathrm{Ag}$ by introducing a $\mathrm{MoO}_{3}$ interlayer (especially when the $\mathrm{MoO}_{3}$ layer is thin). $\mathrm{MoO}_{3}$ works as a surfactant here to modify the surface of Ag film. When the thickness of $\mathrm{MoO}_{3}$ is $2 \mathrm{~nm}$, the unclosed layer may create preferred nucleation sites on the glass substrate to enhance the lateral growth of $\mathrm{Ag}$ film and decrease Ag threshold. The detailed discussion and analysis can be seen in our previous work [33].

Based on this optimal $\mathrm{MoO}_{3}(2 \mathrm{~nm}) / \mathrm{Ag}(9 \mathrm{~nm})$ anode, ITO-free semitransparent OSCs are fabricated with different thickness combination of $\mathrm{Ca}$ and $\mathrm{Ag}$ as the cathodes. $J-V$ characteristics of corresponding OSCs illuminated from the anode or cathode side are shown in Figures 3(a) and 3(b), respectively. Dark $J-V$ curves are also shown in Figure 3(a) for comparison. The corresponding photovoltaic parameters have been summarized in Table 1. As shown in Figure 3(a) and Table 1 , the best performance is obtained for OSCs with
$\mathrm{Ca}(10 \mathrm{~nm}) / \mathrm{Ag}(20 \mathrm{~nm})$ cathode when illuminated from the anode side, with an open-circuit voltage $\left(V_{\mathrm{OC}}\right)$ of $0.64 \mathrm{~V}$, a short-circuit current density $\left(J_{\mathrm{SC}}\right)$ of $5.03 \mathrm{~mA} / \mathrm{cm}^{2}$, a fill factor (FF) of $62.4 \%$, and a PCE of $2.01 \%$. However, when illuminated from the cathode side, a higher $J_{\mathrm{SC}}$ of $1.90 \mathrm{~mA} / \mathrm{cm}^{2}$ and a higher PCE of $0.67 \%$ are obtained for OSCs based on $\mathrm{Ca}$ $(15 \mathrm{~nm}) / \mathrm{Ag}(15 \mathrm{~nm})$ cathode, compared with that of devices with $\mathrm{Ca}(10 \mathrm{~nm}) / \mathrm{Ag}(20 \mathrm{~nm})$ cathode. Moreover, a very low $J_{\mathrm{SC}}$ of $0.31 \mathrm{~mA} / \mathrm{cm}^{2}$ is obtained for OSCs with Ca $(20 \mathrm{~nm}) / \mathrm{Ag}$ $(10 \mathrm{~nm})$ cathode when illuminated from the anode side.

In order to better understand the effect of different cathodes on the device performance, the cathode-only samples of $\mathrm{Ca}(10 \mathrm{~nm}) / \mathrm{Ag}(20 \mathrm{~nm}), \mathrm{Ca}(15 \mathrm{~nm}) / \mathrm{Ag}(15 \mathrm{~nm})$, and $\mathrm{Ca}(20 \mathrm{~nm}) / \mathrm{Ag}(10 \mathrm{~nm})$ are fabricated on glass substrates through the same procedure as the device production and characterized. The wavelength-dependent transmittance and reflectance spectra of these samples are shown in Figure 4. 


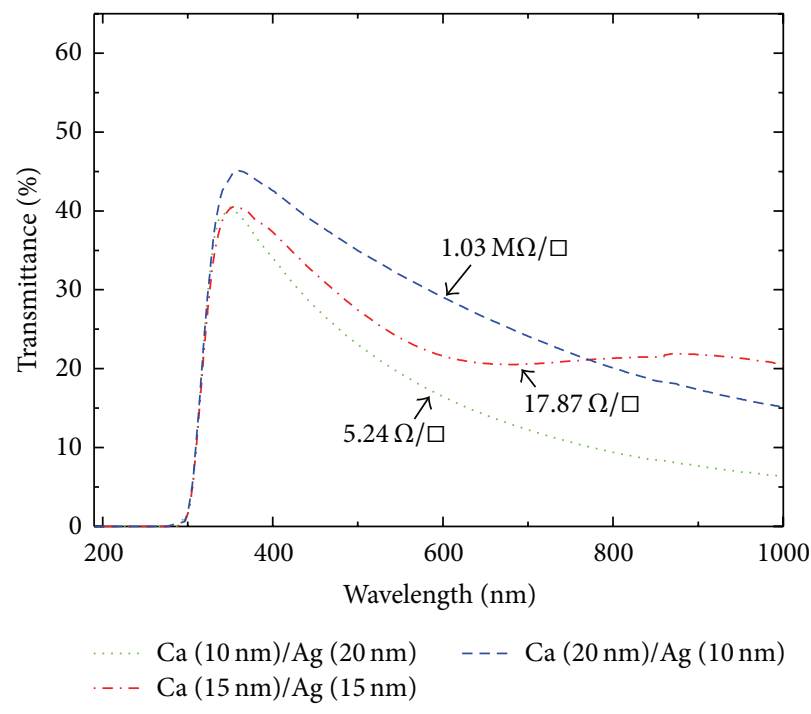

(a)

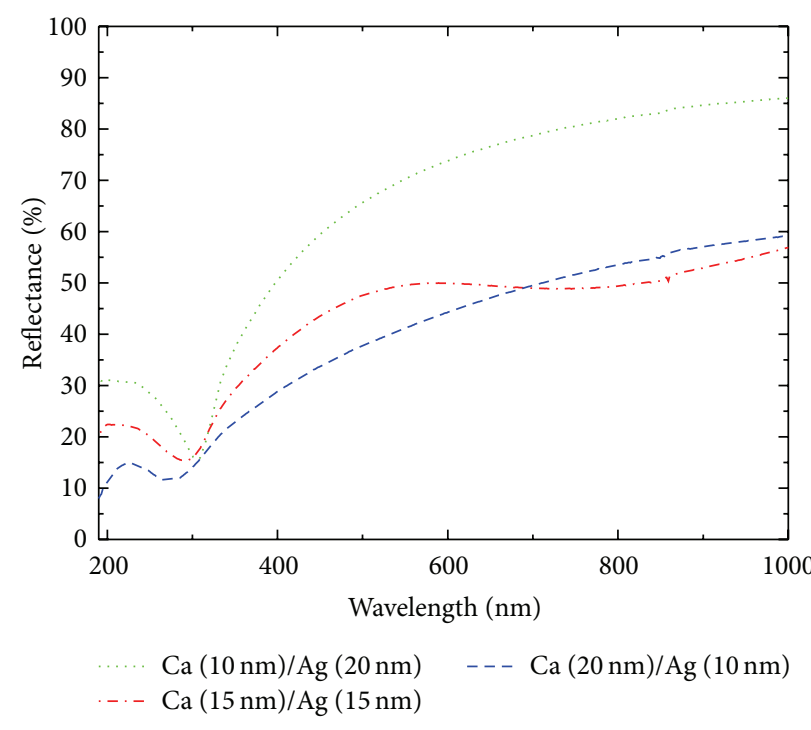

(b)

Figure 4: (a) The wavelength-dependent transmittance spectra with corresponding sheet resistances and (b) the wavelength-dependent reflectance spectra of $\mathrm{Ca}(10 \mathrm{~nm}) / \mathrm{Ag}(20 \mathrm{~nm}), \mathrm{Ca}(15 \mathrm{~nm}) / \mathrm{Ag}(15 \mathrm{~nm})$, and $\mathrm{Ca}(20 \mathrm{~nm}) / \mathrm{Ag}(10 \mathrm{~nm})$ electrodes deposited on glass substrates.

The sheet resistances of these three cathodes are also depicted in Figure 4(a). As shown in Figure 4(a), a large sheet resistance of $1.03 \mathrm{M} \Omega / \square$ is obtained for $\mathrm{Ca}(20 \mathrm{~nm}) / \mathrm{Ag}$ $(10 \mathrm{~nm})$ cathode. This may be caused by that the Ag layer is still not continuous here, in accordance with the previous conclusion that the percolation threshold of $\mathrm{Ag}$ in our case is approximately $11 \mathrm{~nm}$. Meanwhile, the discontinuous Ag layer cannot effectively protect the Ca layer from oxygen and moisture so that $\mathrm{Ca}$ is oxidized, which also increase the sheet resistance. The poor conductivity of this cathode leads to a very low $J_{\mathrm{SC}}$ of $0.31 \mathrm{~mA} / \mathrm{cm}^{2}$ (shown in Table 1).

As shown in Figure 4(a), although both $\mathrm{Ca}(10 \mathrm{~nm}) / \mathrm{Ag}$ $(20 \mathrm{~nm})$ and $\mathrm{Ca}(15 \mathrm{~nm}) / \mathrm{Ag}(15 \mathrm{~nm})$ cathodes show good conductivity with a low sheet resistance, the transparency of $\mathrm{Ca}(15 \mathrm{~nm}) / \mathrm{Ag}(15 \mathrm{~nm})$ cathode is always better than that of $\mathrm{Ca}(10 \mathrm{~nm}) / \mathrm{Ag}(20 \mathrm{~nm})$ cathode in the visible and near infrared spectral range. Thus when illuminated from the cathode side, as shown in Table 1, a higher $J_{\mathrm{SC}}$ of $1.90 \mathrm{~mA} / \mathrm{cm}^{2}$ and a higher PCE of $0.67 \%$ are obtained for OSCs with $\mathrm{Ca}(15 \mathrm{~nm}) / \mathrm{Ag}(15 \mathrm{~nm})$ cathode, compared with that of $\mathrm{Ca}(10 \mathrm{~nm}) / \mathrm{Ag}(20 \mathrm{~nm})$ cathode $\left(J_{\mathrm{SC}}\right.$ of $1.44 \mathrm{~mA} / \mathrm{cm}^{2}$ and PCE of $0.56 \%)$.

However, the situation becomes different when illuminated from the anode side. As shown in Figure 4(b), Ca $(10 \mathrm{~nm}) / \mathrm{Ag}(20 \mathrm{~nm})$ cathode has a stronger reflectance than $\mathrm{Ca}(15 \mathrm{~nm}) / \mathrm{Ag}(15 \mathrm{~nm})$ cathode in the nearly entire spectral range discussed. Thus when illuminated from the anode side, more light is reflected from the $\mathrm{Ca} / \mathrm{Ag}$ surface and arrives at the active layer a second time for OSCs based on $\mathrm{Ca}(10 \mathrm{~nm}) / \mathrm{Ag}(20 \mathrm{~nm})$ cathode. It leads to a higher $J_{\text {SC }}$ of $5.03 \mathrm{~mA} / \mathrm{cm}^{2}$ and a higher PCE of $2.01 \%$, compared with that of $\mathrm{Ca}(15 \mathrm{~nm}) / \mathrm{Ag}(15 \mathrm{~nm})$ cathode $\left(J_{\mathrm{SC}}\right.$ of $4.70 \mathrm{~mA} / \mathrm{cm}^{2}$ and PCE of $1.79 \%)$.
Since good transparency and high PCE should be achieved simultaneously in the application of semitransparent OSCs, samples with the same stack as our devices but a larger area are fabricated. The wavelength-dependent transmittance spectra of corresponding OSCs with different thickness combination of $\mathrm{Ca}$ and $\mathrm{Ag}$ as the cathodes are shown in Figure 5. For comparison, the transmittance spectrum of the stack $\mathrm{MoO}_{3}(2 \mathrm{~nm}) / \mathrm{Ag}(9 \mathrm{~nm}) / \mathrm{MoO}_{3}(10 \mathrm{~nm}) / \mathrm{P} 3 \mathrm{HT}: \mathrm{PCBM}$ (the device without the cathode) is also depicted in Figure 5. It is observed from Figure 5 that the spectral shapes of the transmittance curves are similar for four samples. Two minimums around 500 and $600 \mathrm{~nm}$ represent the absorption peak of P3HT:PCBM. The transparency of OSCs based on $\mathrm{Ca}(10 \mathrm{~nm}) / \mathrm{Ag}(20 \mathrm{~nm})$ cathode is the lowest nearly across the entire spectral range, with a small transparency peak of $16 \%$ at $365 \mathrm{~nm}$. It is in agreement with the results shown in Figure 4. The best transparency is obtained for OSCs with $\mathrm{Ca}(15 \mathrm{~nm}) / \mathrm{Ag}(15 \mathrm{~nm})$ cathode, with a maximum of $32 \%$ at $690 \mathrm{~nm}$. Meanwhile the performance of this device (PCE of $1.79 \%$ and $0.67 \%$ for illumination from the anode and cathode side, resp.) is comparable to that of similar ITO-based semitransparent OSCs (PCE of $1.59 \%$ and $0.75 \%$ for illumination from the anode and cathode side, resp.) $[10,11]$. Thus ITOfree semitransparent OSCs based on Ca $(15 \mathrm{~nm}) / \mathrm{Ag}(15 \mathrm{~nm})$ cathode are more preferred for the application.

Moreover, the stability has also been investigated for ITO-free semitransparent OSCs with Ca $(15 \mathrm{~nm}) / \mathrm{Ag}(15 \mathrm{~nm})$ cathode. The unencapsulated OSCs were stored in the glove box and measured in air ambient conditions. The normalized PCE as a function of time is shown in Figure 6. As shown in Figure 6, PCE of the device remains $70 \%$ of the original efficiency after $262 \mathrm{~h}$ no matter the OSC is illuminated from the anode or cathode side. It is expected that the better stability could be obtained for our encapsulated ITO-free 


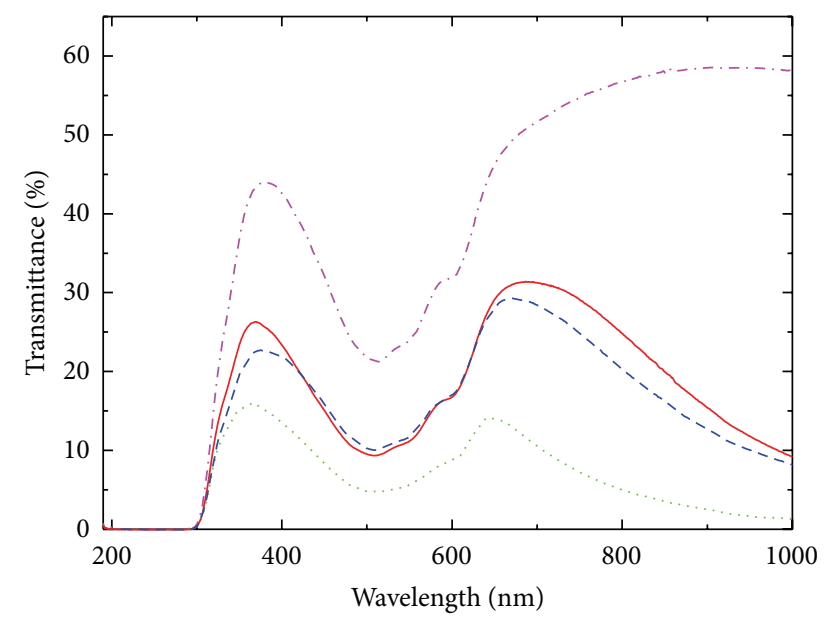

$\begin{array}{ll}\text { - Without cathode } & \mathrm{Ca}(15 \mathrm{~nm}) / \mathrm{Ag}(15 \mathrm{~nm}) \\ \text {... Ca }(10 \mathrm{~nm}) / \mathrm{Ag}(20 \mathrm{~nm}) & --\mathrm{Ca}(20 \mathrm{~nm}) / \mathrm{Ag}(10 \mathrm{~nm})\end{array}$

FIGURE 5: The wavelength-dependent transmittance spectra of ITO-free semitransparent OSCs with different thickness combination of $\mathrm{Ca}$ and $\mathrm{Ag}$ as the cathodes. For comparison, the transmittance spectrum of the stack $\mathrm{MoO}_{3}(2 \mathrm{~nm}) / \mathrm{Ag}(9 \mathrm{~nm}) / \mathrm{MoO}_{3}$ $(10 \mathrm{~nm}) / \mathrm{P} 3 \mathrm{HT}: \mathrm{PCBM}$ (the device without the cathode) is also depicted in Figure 5. Bottom illumination from the anode side is applied for measurement.

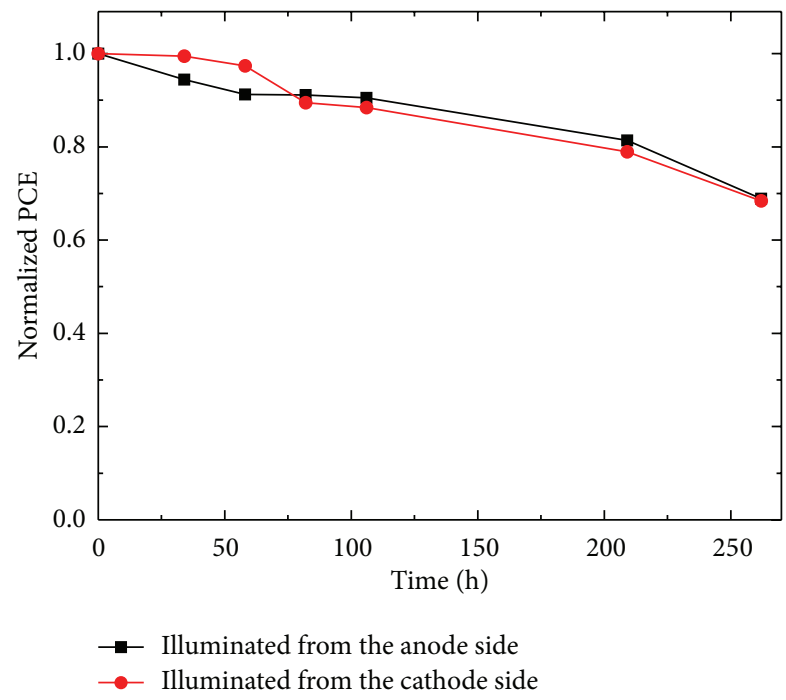

FIGURE 6: The variation of the normalized PCE with time.

semitransparent OSCs by avoiding oxidation and mechanical damage.

\section{Conclusions}

In this paper, we have firstly demonstrated efficient ITOfree reference OSCs based on $\left(\mathrm{MoO}_{3}\right) / \mathrm{Ag}$ anodes. The PCE of $2.71 \%$ is obtained for OSCs based on the optimal $\mathrm{MoO}_{3}$ $(2 \mathrm{~nm}) / \mathrm{Ag}(9 \mathrm{~nm})$ anode (also the highest PCE among all the ITO-free reference OSCs), comparable to that of ITObased reference OSCs (PCE of 2.85\%). Then based on this
$\mathrm{MoO}_{3}(2 \mathrm{~nm}) / \mathrm{Ag}(9 \mathrm{~nm})$ anode, ITO-free semitransparent OSCs with different thickness combination of $\mathrm{Ca}$ and $\mathrm{Ag}$ as the cathodes are fabricated. It combines the advantages of ITO-free OSCs and semitransparent OSCs simultaneously, providing a way for commercialization of OSCs. It is observed from our results that OSCs with $\mathrm{Ca}(15 \mathrm{~nm}) / \mathrm{Ag}(15 \mathrm{~nm})$ cathode have the optimal transparency. Meanwhile, the PCE of $1.79 \%$ (illuminated from the anode side) and $0.67 \%$ (illuminated from the cathode side) is obtained, comparable to that of similar ITO-based semitransparent OSCs (PCE of $1.59 \%$ and $0.75 \%$ for illumination from the anode and cathode side, resp.) $[10,11]$. Although all the devices are only fabricated on glass substrates, our method and process can also be applied to flexible substrates. Meanwhile, the transparency and PCE of ITO-free semitransparent OSCs can be further improved by introducing a light couple layer. These results are instructive for further research of ITO-free semitransparent OSCs.

\section{Conflict of Interests}

The authors declare that there is no conflict of interests regarding the publication of this paper.

\section{Acknowledgment}

The authors gratefully acknowledge the support of NSFC (61106063).

\section{References}

[1] C. J. Brabec, "Organic photovoltaics: technology and market," Solar Energy Materials and Solar Cells, vol. 83, no. 2-3, pp. 273292, 2004.

[2] P. Peumans, A. Yakimov, and S. R. Forrest, "Small molecular weight organic thin-film photodetectors and solar cells," Journal of Applied Physics, vol. 93, no. 7, pp. 3693-3723, 2003.

[3] R. Søndergaard, M. Helgesen, M. Jørgensen, and F. C. Krebs, "Fabrication of polymer solar cells using aqueous processing for all layers including the metal back electrode," Advanced Energy Materials, vol. 1, no. 1, pp. 68-71, 2011.

[4] F. C. Krebs, "Fabrication and processing of polymer solar cells: a review of printing and coating techniques," Solar Energy Materials and Solar Cells, vol. 93, no. 4, pp. 394-412, 2009.

[5] H. F. Dam and F. C. Krebs, "Simple roll coater with variable coating and temperature control for printed polymer solar cells," Solar Energy Materials and Solar Cells, vol. 97, pp. 191-196, 2012.

[6] M. A. Green, K. Emery, Y. Hishikawa, W. Warta, and E. D. Dunlop, "Solar cell efficiency tables (version 40)," Progress in Photovoltaics: Research and Applications, vol. 20, no. 5, pp. 606614, 2012

[7] R. Schueppel, R. Timmreck, N. Allinger et al., "Controlled current matching in small molecule organic tandem solar cells using doped spacer layers," Journal of Applied Physics, vol. 107, no. 4, Article ID 044503, 2010.

[8] D. W. Zhao, X. W. Sun, C. Y. Jiang, A. K. K. Kyaw, G. Q. Lo, and D. L. Kwong, "Efficient tandem organic solar cells with an Al/ $\mathrm{MoO}_{3}$ intermediate layer," Applied Physics Letters, vol. 93, no. 8, Article ID 083305, 2008. 
[9] A. Hadipour, B. de Boer, and P. W. M. Blom, "Device operation of organic tandem solar cells," Organic Electronics, vol. 9, no. 5, pp. 617-624, 2008.

[10] F. Li, S. Ruan, Y. Xu et al., "Semitransparent inverted polymer solar cells using $\mathrm{MoO}_{3} / \mathrm{Ag} / \mathrm{WO}_{3}$ as highly transparent anodes," Solar Energy Materials and Solar Cells, vol. 95, no. 3, pp. 877880, 2011.

[11] L. Shen, S. Ruan, W. Guo, F. Meng, and W. Chen, "Semitransparent inverted polymer solar cells using $\mathrm{MoO}_{3} / \mathrm{Ag} / \mathrm{V}_{2} \mathrm{O}_{5}$ as transparent anodes," Solar Energy Materials \& Solar Cells, vol. 97, pp. 59-63, 2012.

[12] L. Shen, Y. Xu, F. Meng, F. Li, S. Ruan, and W. Chen, "Semitransparent polymer solar cells using $\mathrm{V}_{2} \mathrm{O}_{5} / \mathrm{Ag} / \mathrm{V}_{2} \mathrm{O}_{5}$ as transparent anodes," Organic Electronics: Physics, Materials, Applications, vol. 12, no. 7, pp. 1223-1226, 2011.

[13] D. S. Hecht, L. Hu, and G. Irvin, "Emerging transparent electrodes based on thin films of carbon nanotubes, graphene, and metallic nanostructures," Advanced Materials, vol. 23, no. 13, pp. 1482-1513, 2011.

[14] J. Lee, S. T. Connor, Y. Cui, and P. Peumans, "Solution-processed metal nanowire mesh transparent electrodes," Nano Letters, vol. 8, no. 2, pp. 689-692, 2008.

[15] H. Chen, A. du Pasquier, G. Saraf, J. Zhong, and Y. Lu, "Dyesensitized solar cells using $\mathrm{ZnO}$ nanotips and Ga-doped $\mathrm{ZnO}$ films," Semiconductor Science and Technology, vol. 23, no. 4, Article ID 045004, 2008.

[16] H. Park, J. Kang, S. Na, D. Kim, and H. Kim, "Characteristics of indium-free $\mathrm{GZO} / \mathrm{Ag} / \mathrm{GZO}$ and $\mathrm{AZO} / \mathrm{Ag} / \mathrm{AZO}$ multilayer electrode grown by dual target $\mathrm{DC}$ sputtering at room temperature for low-cost organic photovoltaics," Solar Energy Materials and Solar Cells, vol. 93, no. 11, pp. 1994-2002, 2009.

[17] N. Sun, G. Fang, P. Qin et al., "Bulk heterojunction solar cells with $\mathrm{NiO}$ hole transporting layer based on AZO anode," Solar Energy Materials and Solar Cells, vol. 94, no. 12, pp. 2328-2331, 2010.

[18] Y. H. Kim, C. Sachse, M. L. MacHala, C. May, L. MüllerMeskamp, and K. Leo, "Highly conductive PEDOT:PSS electrode with optimized solvent and thermal post-treatment for ITO-free organic solar cells," Advanced Functional Materials, vol. 21, no. 6, pp. 1076-1081, 2011.

[19] S. Choi, W. J. Potscavage Jr., and B. Kippelen, "ITO-free largearea organic solar cells," Optics Express, vol. 18, no. 19, pp. A458A466, 2010.

[20] F. Guo, X. Zhu, K. Forberich et al., "ITO-free and fully solutionprocessed semitransparent organic solar cells with high fill factors," Advanced Energy Materials, vol. 3, no. 8, pp. 1062-1067, 2013.

[21] J. van de Lagemaat, T. M. Barnes, G. Rumbles et al., "Organic solar cells with carbon nanotubes replacing $\operatorname{In}_{2} \mathrm{O}_{3}$ : $\mathrm{Sn}$ as the transparent electrode," Applied Physics Letters, vol. 88, no. 23, Article ID 233503, 2006.

[22] D. Angmo and F. C. Krebs, "Flexible ITO-free polymer solar cells," Journal of Applied Polymer Science, vol. 129, no. 1, pp. 1-14, 2013.

[23] L. Cattin, J. C. Bernède, and M. Morsli, "Toward indium-free optoelectronic devices: dielectric/metal/dielectric alternative transparent conductive electrode in organic photovoltaic cells," Physica Status Solidi (A): Applications and Materials Science, vol. 210, no. 6, pp. 1047-1061, 2013.

[24] W. Cao, Y. Zheng, Z. Li, E. Wrzesniewski, W. T. Hammond, and J. Xue, "Flexible organic solar cells using an oxide/metal/oxide trilayer as transparent electrode," Organic Electronics, vol. 13, no. 11, pp. 2221-2228, 2012.

[25] S. D. Yambem, A. Haldar, K. Liao, E. P. Dillon, A. R. Barron, and S. A. Curran, "Optimization of organic solar cells with thin film Au as anode," Solar Energy Materials and Solar Cells, vol. 95, no. 8, pp. 2424-2430, 2011.

[26] S. D. Yambem, K. Liao, and S. A. Curran, "Flexible Ag electrode for use in organic photovoltaics," Solar Energy Materials and Solar Cells, vol. 95, no. 11, pp. 3060-3064, 2011.

[27] S. Lim, D. Han, H. Kim, S. Lee, and S. Yoo, "Cu-based multilayer transparent electrodes: a low-cost alternative to ITO electrodes in organic solar cells," Solar Energy Materials and Solar Cells, vol. 101, pp. 170-175, 2012.

[28] D. S. Ghosh, R. Betancur, T. L. Chen, V. Pruneri, and J. Martorell, "Semi-transparent metal electrode of $\mathrm{CuNi}$ as a replacement of an ITO in organic photovoltaic cells," Solar Energy Materials and Solar Cells, vol. 95, no. 4, pp. 1228-1231, 2011.

[29] R. Sennett and G. Scott, "The structure of evaporated metal films and their optical properties," Journal of the Optical Society of America, vol. 40, pp. 203-210, 1950.

[30] S. Kim, H. Ee, W. Choi et al., "Surface-plasmon-induced light absorption on a rough silver surface," Applied Physics Letters, vol. 98, no. 1, Article ID 011109, 2011.

[31] S. Schubert, J. Meiss, L. Müller-Meskamp, and K. Leo, "Improvement of transparent metal top electrodes for organic solar cells by introducing a high surface energy seed layer," Advanced Energy Materials, vol. 3, no. 4, pp. 438-443, 2013.

[32] S. Schubert, M. Hermenau, J. Meiss, L. Müller-Meskamp, and K. Leo, "Oxide sandwiched metal thin-film electrodes for longterm stable organic solar cells," Advanced Functional Materials, vol. 22, no. 23, pp. 4993-4999, 2012.

[33] Z. Wang, C. Zhang, R. Gao et al., "Improvement of transparent silver thin film anodes for organic solar cells with a decreased percolation threshold of silver," Solar Energy Materials and Solar Cells, vol. 127, pp. 193-200, 2014. 

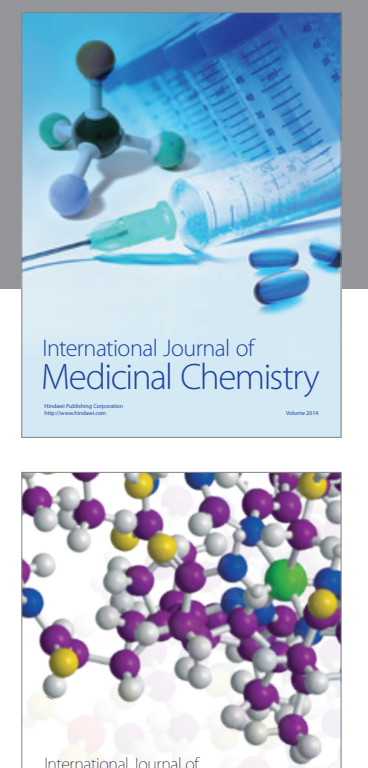

\section{Carbohydrate} Chemistry

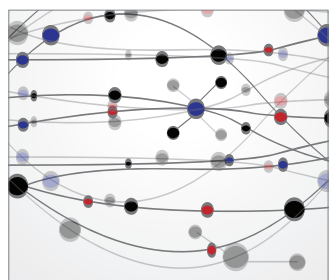

The Scientific World Journal
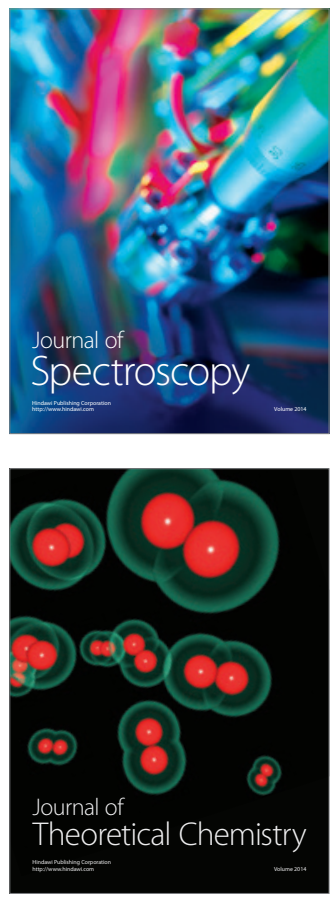
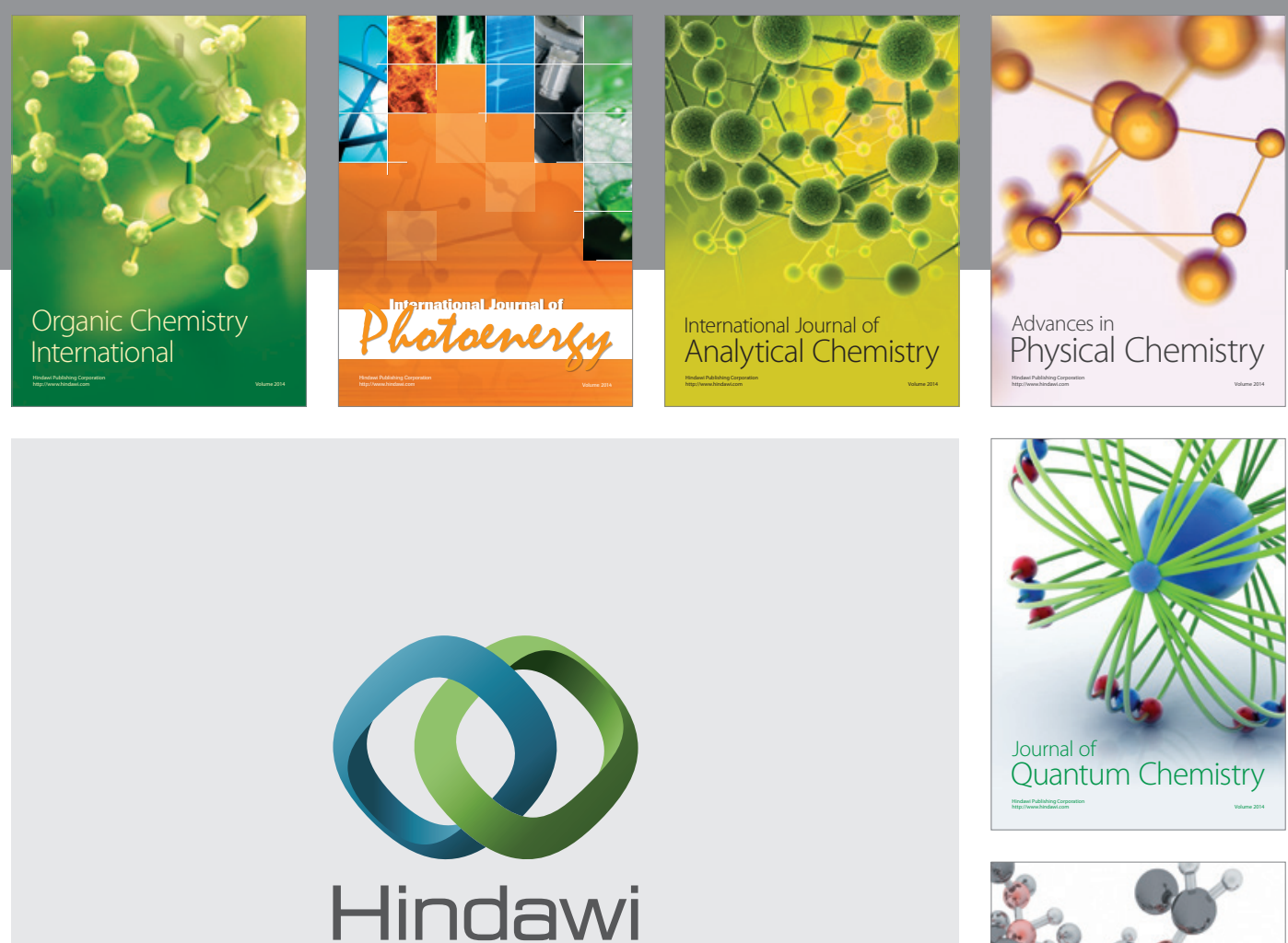

Submit your manuscripts at

http://www.hindawi.com

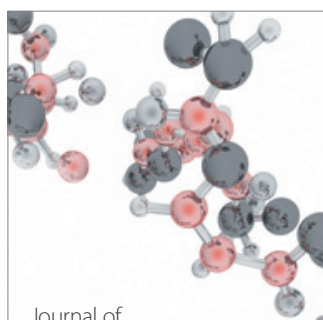

Analytical Methods

in Chemistry

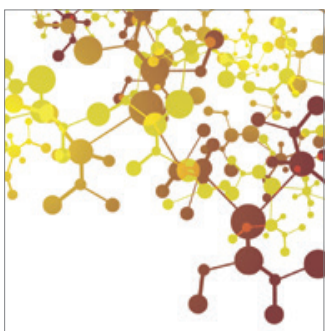

Journal of

Applied Chemistry

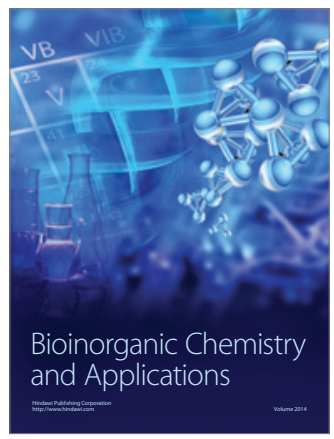

Inorganic Chemistry
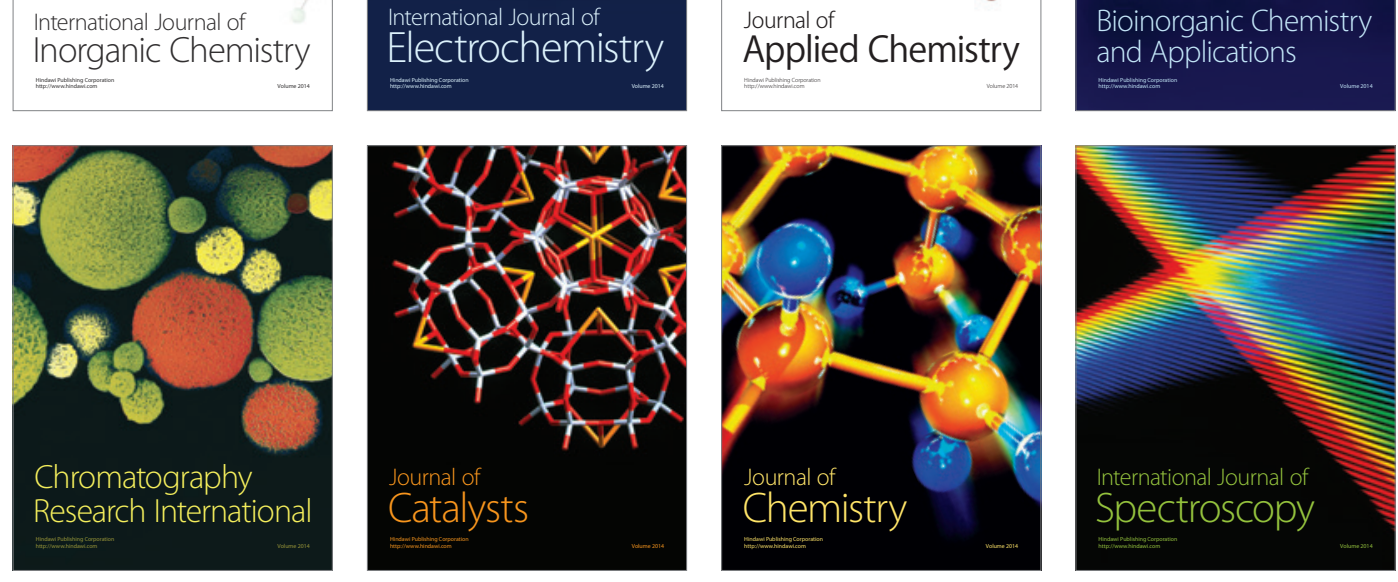